University of Nebraska - Lincoln

DigitalCommons@University of Nebraska - Lincoln

USDA National Wildlife Research Center - Staff Publications
U.S. Department of Agriculture: Animal and Plant Health Inspection Service

2012

\title{
Reducing Impacts of Double-crested Cormorants to Natural Resources in Central New York: A Review of a Collaborative Research, Management, and Monitoring Program
}

Travis L. DeVault

USDA/APHIS/WS National Wildlife Research Center, Travis.L.DeVault@aphis.usda.gov

Richard B. Chipman

USDA, APHIS, Wildlife Services

Scott C. Barras

USDA, APHIS, Wildlife Services

Jimmy D. Taylor II

USDA/APHIS/WS National Wildlife Research Center, jimmy.d.taylor@usda.gov

Carl P. Cranker III

USDA, APHIS, Wildlife Services

See next page for additional authors

Follow this and additional works at: https://digitalcommons.unl.edu/icwdm_usdanwrc

Part of the Life Sciences Commons

DeVault, Travis L.; Chipman, Richard B.; Barras, Scott C.; Taylor, Jimmy D. II; Cranker, Carl P. III; Cranker, Elizabeth M.; and Farquhar, James F., "Reducing Impacts of Double-crested Cormorants to Natural Resources in Central New York: A Review of a Collaborative Research, Management, and Monitoring Program" (2012). USDA National Wildlife Research Center - Staff Publications. 1458.

https://digitalcommons.unl.edu/icwdm_usdanwrc/1458

This Article is brought to you for free and open access by the U.S. Department of Agriculture: Animal and Plant Health Inspection Service at DigitalCommons@University of Nebraska - Lincoln. It has been accepted for inclusion in USDA National Wildlife Research Center - Staff Publications by an authorized administrator of DigitalCommons@University of Nebraska - Lincoln. 


\section{Authors}

Travis L. DeVault, Richard B. Chipman, Scott C. Barras, Jimmy D. Taylor II, Carl P. Cranker III, Elizabeth M. Cranker, and James F. Farquhar 


\title{
Reducing Impacts of Double-crested Cormorants to Natural Resources in Central New York: A Review of a Collaborative Research, Management, and Monitoring Program
}

\author{
Travis L. DeVault ${ }^{1, *}$, Richard B. Chipman ${ }^{2}$, Scott C. Barras ${ }^{3}$, Jimmy D. Taylor ${ }^{4}$, Carl P. \\ Cranker III $^{5}$, Elizabeth M. Cranker ${ }^{5}$ and James F. Farquhar ${ }^{6}$ \\ ${ }^{1}$ USDA, APHIS, Wildlife Services, National Wildlife Research Center, 6100 Columbus Avenue, \\ Sandusky, OH, 44870, USA
}

${ }^{2}$ USDA, APHIS, Wildlife Services, National Rabies Management Program, 59 Chenell Drive, Suite 2, Concord, NH, 03301, USA

${ }^{3}$ USDA, APHIS, Wildlife Services, 21425 Hull Street Road, Moseley, VA, 23120, USA

${ }^{4}$ USDA, APHIS, Wildlife Services, National Wildlife Research Center, 321 Richardson Hall, Oregon State University, Corvallis, Oregon, 97331, USA

${ }^{5}$ USDA, APHIS, Wildlife Services, 5757 Sneller Road, Brewerton, NY, 13029, USA

${ }^{6}$ New York State Department of Environmental Conservation, Division of Fish, Wildlife, and Marine Resources, 317 Washington Street, Watertown, NY, 13601, USA

*Corresponding author; E-mail: Travis.L.DeVault@aphis.usda.gov

\begin{abstract}
Double-crested Cormorants (Phalacrocorax auritus) have used central New York waters for breeding and stopover habitats during migration since 1984. In response to public concern over Oneida Lake, the United States Department of Agriculture Wildlife Services and the New York State Department of Environmental Conservation initiated an integrated research, management and monitoring program aimed at mitigating cormorant impacts to fisheries and other natural resources in 1998. The history of this program was reviewed and efforts to reduce negative impacts of the Double-crested Cormorant population in central New York described. Management was successful, as demonstrated by a substantial decrease in cormorant use of Oneida Lake during spring, summer and fall seasons, and the apparent recovery of certain sportfish populations. Research identified cormorant movement patterns within and among water bodies and documented cormorant responses to hazing and other management techniques. The cormorant management program in central New York was intended to keep cormorant use of Oneida Lake at a level that prevents unsustainable impacts to fisheries populations. Received 14 September 2007, accepted 8 December 2008.

Key words.-Double-crested Cormorant, harassment, management, monitoring, New York, non-lethal management, Oneida Lake, wildlife management.
\end{abstract}

Waterbirds 35(Special Publication 1): 50-55, 2012

From the mid-1970s until recently, the Double-crested Cormorant (Phalacrocorax auritus; hereafter cormorant) population increased dramatically in the Great Lakes region, including central New York (Weseloh and Ewins 1994; Hatch 1995; Weseloh et al. 1995; Hatch and Weseloh 1999). The population of cormorants across the Great Lakes region in the mid-2000s exceeded 350,000 (Shauna Hanisch, Michigan State University, pers. comm.), and caused damage to recreational fisheries (Rudstam et al. 2004), vegetation (Lemmon et al. 1994; Hebert et al. 2005), and other colonial-nesting birds (Jarvie et al. 1999; Shieldcastle and Martin 1999). As such, cormorants are managed on the breeding grounds and during migration in several Great Lakes states and in Ontario to alleviate damage and lessen conflicts with human interests (e.g. Bedard et al. 1999; Chipman et al. 2000).

In New York, cormorant management and monitoring programs were implemented to protect fisheries and vegetation in the eastern basin of Lake Ontario (Farquhar et al. this issue), the Niagara Frontier, the St. Lawrence River and central New York. From 2004 to 2006 across New York State, 13,114 cormorant nests were oiled or destroyed, and 4,071 birds were killed to protect natural resources (S. Hanisch, pers. comm.). The cormorant population in New York State in 2006 was an estimated 23,000 individuals. 
Research on Oneida Lake in central New York has demonstrated that cormorant consumption of Walleye (Stizostedion vitreum) and adult Yellow Perch (Perca flavescens) was similar to levels harvested by anglers, although cormorants consumed many more juvenile Yellow Perch than did anglers (VanDeValk et al. 2002). For example, in 1997, the estimated angler harvest of Walleye (all ages) in Oneida Lake was 35,400 individuals, whereas the estimated cormorant consumption ranged from 27,300 to 32,700 (VanDeValk et al. 2002). For adult (age $\geq 3$ years) Yellow Perch, anglers harvested an estimated 93,700 in Oneida Lake in 1997 compared to 97,000 to 112,600 harvested by cormorants (VanDeValk et al. 2002). Rudstam et al. (2004) determined that cormorant predation was a major factor contributing to population declines in those species in Oneida Lake.

The United States Department of Agriculture (USDA) Wildlife Services began managing and monitoring cormorants in central New York in 1998 (Chipman et al. 2000), and continued until 2009, when funding for the program was discontinued. Management and monitoring efforts in central New York were expanded during that time, and research was conducted to document patterns of cormorant movements in response to management. The central New York cormorant program was unique among other local cormorant management programs in the Great Lakes region because it relied primarily on non-lethal methods. Additionally, it was an adaptive management program that included three major components: management, monitoring and research. Here, we review the history and status of the cormorant management program by the USDA Wildlife Services in central New York from 1998 to 2009, especially on Oneida Lake, and discuss the complexity and challenges that faced the program.

STUdy AREA

and History of Cormorants on Oneida Lake

Oneida Lake $\left(43^{\circ} 14^{\prime} \mathrm{N}, 076^{\circ} 00^{\prime} \mathrm{W}\right)$ is a large $(207$ $\mathrm{km}^{2}$ ) lake in central New York (Mills et al. 1978) which supports major fisheries for Walleye and Yellow Perch (Connelly and Brown 1991; Fig. 1). Cormorants first nested on Oneida Lake in 1984 (Claypoole 1988), and by 1990 there were 62 nesting pairs (Milo Richmond and Jeremy Coleman, Cornell University, pers. comm.). By 1997, the population had grown to 269 nesting pairs, with approximately 2,700 individuals present on the lake during fall migration (M. Richmond and J. Coleman, pers. comm.). Concern over cormorant impacts to fish populations began in the late 1980s and early 1990s as populations of Walleye and Yellow Perch began to decline from long-term averages (VanDeValk et al. 2007).

In response to public concerns in 1994 and again in 2003, the New York State Department of Environmental Conservation (NYSDEC) convened "Citizen Task Force" meetings to involve the public in the decision-making process concerning cormorant management. The process involved bringing together representatives of key stakeholder groups with a focus on Lake Ontario (1994 only) and Oneida Lake along with scientific advisors in a facilitated meeting with the goal of providing recommendations to NYSDEC regarding cormorant population and management objectives. The primary recommendation relating to Oneida Lake made by the Citizen Task Force in 1994 was to minimize the fall stopover of cormorants on the lake by direct human harassment and/or mechanical harassment to minimize cormorant predation on Walleye and Yellow Perch. At that time, state and federal regulatory agencies in the northeast limited the techniques that could be used to manage cormorants to primarily non-lethal methods. As a result, based on the Citizen Task Force recommendations and at the request of NYSDEC, USDA Wildlife Services designed and implemented a unique, lake-wide, nonlethal hazing program that was first initiated during the fall migration period in 1998.

A second Citizen Task Force meeting was convened in 2003 and made further recommendations to intensify management to reduce the cormorant population on Oneida Lake to a target population goal of 100 individuals, including 20 nesting pairs, and where practical mitigate offsite impacts of displaced cormorants on nearby lakes. In response, USDA Wildlife Services expanded the harassment program in 2004 to include the period from ice-out in spring through fall (excluding the month of May; see below). Also beginning in 2004, cormorant harassment was expanded to Onondaga Lake (12 km²; Fig. 1) in the city of Syracuse, and a longterm monitoring protocol was established.

\section{Management}

Cormorant management to protect fisheries on Oneida Lake was primarily a nonlethal harassment program. Wildlife Services employees used boat chases, pyrotechnics, Mylar tape, human effigies, nest treatment (nest destruction and egg oiling), and since 2004, limited lethal removal by shooting juvenile and adult cormorants to reduce fisheries impacts in the lake. Harassment by py- 


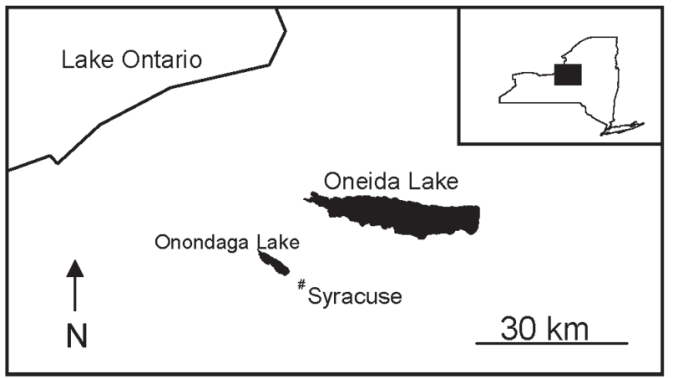

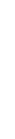

Figure 1. Location of Oneida Lake $\left(43^{\circ} 14^{\prime} \mathrm{N}, 076^{\circ} 00^{\prime}\right.$ $\mathrm{W})$ and Onondaga Lake $\left(43^{\circ} 05^{\prime} \mathrm{N}, 076^{\circ} 12^{\prime} \mathrm{W}\right)$ in central New York, USA.

rotechnics and boat chases were the primary method used to deter cormorant use of central New York waters. From 2004 through 2009 , an annual mean (SD) of 9,753 $(6,004)$ pyrotechnics were used to harass 66,922 $(35,816)$ cormorants (many individuals may have been harassed multiple times) using 1,639 (622) staff hours in central New York (Table 1).

Cormorant harassment consisted of three temporal phases: spring, summer and fall. During spring and fall (when cormorant numbers were highest because of migration), intensive harassment was conducted from dawn to dusk, with two boats on Oneida Lake and one boat on Onondaga Lake. Spring harassment generally began shortly after ice-out (usually early to mid-April) and continued until the beginning of May. All cormorant harassment activities were suspended during the month of May to allow Common Terns (Sterna hirundo) to establish nests without disturbance (see Mattison 2006). Summer harassment generally began in the first week of June and ended in mid-August. During summer harassment, one boat was used on each lake to harass cormorants for eight hours per day. Intensive harassment resumed in mid-August (fall harassment) and continued until the end of September.

In addition to harassment from boats, several other methods were used to manage cormorants. Human effigies, electronic scarecrows, monofilament grids and Mylar tape were used to deter cormorants from loafing and nesting on small islands in Oneida Lake. Furthermore, a limited number of cormorants were removed with shotguns each year

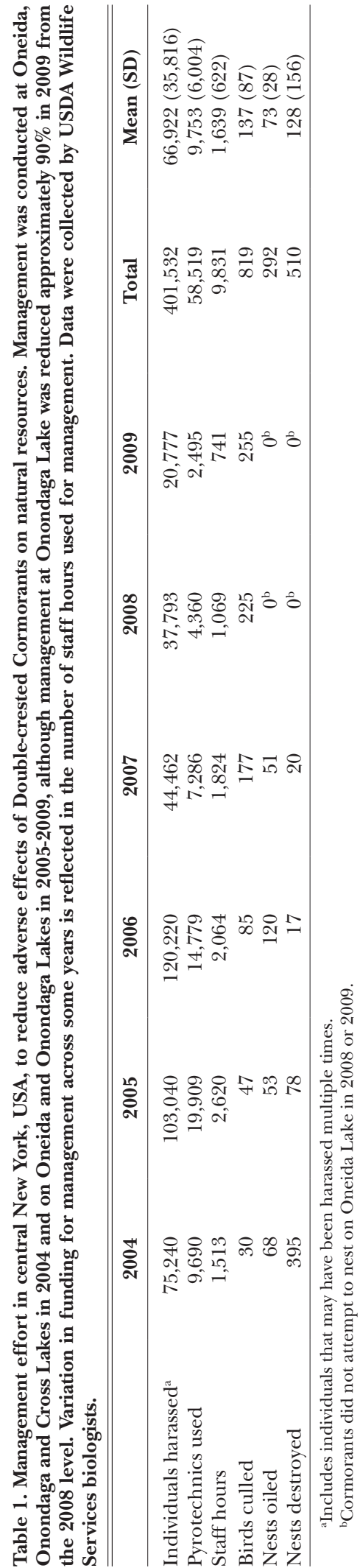


to prevent habituation to non-lethal management and to provide samples for dietary studies (e.g. Rudstam et al. 2004). From 2004 to 2009, an annual mean of 137 (87) cormorants were collected from Oneida and Onondaga Lakes. Cormorant nests also were managed at Oneida Lake and the immediate surroundings; from 2004 to 2009, an annual mean of 73 (28) nests were oiled and 128 (156) nests were destroyed (Table 1).

\section{MONITORING}

Cormorant population monitoring by USDA Wildlife Services began with the onset of cormorant management in the fall of 1998. From 1998 though 2003, fall surveys were conducted weekly by boat to determine the number of cormorants using Oneida Lake during the migratory period. From 20042009, cormorant surveys were conducted twice weekly by boat from early spring through fall on Oneida and Onondaga Lakes (J. D. Taylor, unpublished data). Surveys of all other major water bodies within a $60-\mathrm{km}$ radius of Oneida Lake were also conducted weekly by automobile to discover new nesting colonies and to document cormorant movements within central New York. Additionally, cormorant nests on Oneida Lake were counted and monitored throughout the nesting period by USDA Wildlife Services from 2004-2009.

Monitoring demonstrated the effects of harassment on cormorant population size. For example, in 2006 biologists surveyed a mean of 129 (66) cormorants per survey on Oneida Lake from April through September, and during much of the summer; fewer than 100 birds were found on the lake. In the mid- to late 1990s before cormorant management began on Oneida Lake, 200 to 300 cormorants used the lake throughout the summer months, and counts of 2,000 or more were common during the fall (M. Richmond and J. Coleman, pers. comm.).

\section{RESEARCH}

Barras and Tobin (2003) argued that because research activities can quantify cormorant impacts on natural resources and the aquaculture industry, and can evaluate various management strategies, research must be an active component of cormorant management. From 1998 through 2002, cormorant management efforts on Oneida Lake focused on reducing cormorant use during the month of September, when population counts were highest during fall migration. During this period, weekly cormorant counts demonstrated that cormorant use was reduced substantially after one week of harassment each September. Public concerns in 2002-2003 suggested that despite an effective fall program, levels of cormorant use and associated impact on the fishery during spring and summer months were unacceptable and increased hazing efforts were necessary.

In spring 2003, hazing was initiated two weeks earlier (August), and a research study was included in the central New York cormorant management plan to determine the effects of hazing on cormorant movements. Cormorants captured on the breeding colony on Oneida Lake were fitted with radio telemetry transmitters and monitored daily to determine whether hazing reduced their use of Oneida Lake. In 2004 to 2006, captured individuals were fitted with platform terminal transmitters which provided hourly locations. Researchers hypothesized that spring and summer hazing would 1) decrease the number of cormorants attempting to breed on Oneida Lake; 2) reduce stopover of cormorants during southerly migration and cause individuals to migrate earlier; 3) increase use of adjacent lakes in the central New York watershed but that continued harassment would prevent development of new breeding colonies; and 4) cause individuals to not return to Oneida Lake to breed in subsequent years.

\section{Discussion}

Prior to the implementation of the U.S. Fish and Wildlife Service's Public Resource Depredation Order (PRDO) in 2003 (USDI FWS 2003), it was unusual for state, federal and tribal governments to kill cormorants to protect natural resources, including sportfish, even under permit. As such, the primary cormorant management options available in 1998 at the start of the cooperative man- 
agement program on Oneida Lake involved non-lethal techniques. Even without lethal options, research and monitoring efforts have demonstrated that cormorant management using primarily non-lethal methods in central New York was successful, as evident from the reduction in cormorant numbers over time. The number of cormorants using Oneida Lake declined steadily since management began (J. D. Taylor, unpublished data), and sportfish populations have increased during that time period (VanDeValk et al. 2007). Furthermore, cormorant management did not have a measurable adverse impact on the Common Tern population or on tern behavior at Oneida Lake (Mattison 2006). Much of the success of this program can be attributed to taking a collaborative approach that involved state and federal agencies, universities and the support of lake users that focused on refining management and research through adaptive management processes.

The intent of the PRDO was to provide an additional tool for resolving conflicts with cormorants at the local scale. However, dispersed cormorants may be involved in similar conflicts at their new locations. During the first few years of the cormorant program at Oneida Lake, many cormorants relocated to nearby Onondaga Lake. However, from 2004 to 2009, biologists harassed cormorants at Onondaga Lake, and cormorant use of Onondaga Lake was reduced to negligible levels during most of the breeding season. Recent research has demonstrated that many birds harassed at Oneida and Onondaga Lakes have dispersed widely to various locations in Lake Ontario, the St. Lawrence River and elsewhere; however, no new breeding colonies were detected (J. D. Taylor, unpublished data). Furthermore, most cormorants that moved to existing breeding colonies elsewhere were not present long enough to fledge young (J. D. Taylor, unpublished data). Despite the original intent of the PRDO to reduce local conflicts, management should be conducted in a responsible manner such that non-lethal dispersal does not merely move the problem elsewhere. Additionally, monitoring should be designed and conducted in such a manner that the effects of management are captured.
Despite the success of the program, questions remain about the cost-effectiveness of non-lethal management, such as the harassment-based methods used in central New York (Taylor and Dorr 2003). Furthermore, harassment-based management is feasible only in locations that are easily accessible. Shooting reproductive adults is generally the quickest and least expensive method to reduce cormorant populations (Blackwell et al. 2002), although lethal removal by shooting is often controversial. Even so, shooting and egg-oiling (Shonk et al. 2004) have been used broadly to reduce impacts of cormorants to natural resources in the Great Lakes region since the PRDO was established. Cormorant management programs should be designed based on ecological, social and economic considerations, as well as the characteristics of the target colony being managed.

While this program achieved local success in reducing impacts, effects at the regional level remain unknown. Nevertheless, it is likely that multiple localized efforts such as this conducted simultaneously over a large scale could prevent nesting attempts and affect population growth. With over 350,000 cormorants in the Great Lakes, and given their ability to move between distant water bodies, cormorant numbers could increase following a cessation of management. Likewise, cormorants can quickly establish new breeding colonies near large water bodies. Regional plans must be able to rapidly assess and respond to changes in habitat utilization as cormorant populations continue to expand and react to large-scale management efforts. As demonstrated by the program at Oneida Lake, successful management can be achieved through a collaborative approach involving citizens, state, federal and provincial programs.

\section{ACKNOWLEDGMENTS}

We thank M. Lowney, M. Carrara, K. Preusser, J. Gansowski, B. Dorr, L. Rudstam, R. Jackson, E. Mills, M. Richmond, J. Coleman, T. VanDeValk, D. Adams, C. Adams, I. Mazzocchi, S. Hanisch, scores of technicians and the members of the Oneida Lake Association for helping to make the cormorant program in central New York a success. 


\section{Literature Cited}

Barras, S. C. and M. E. Tobin. 2003. The role of research in expanded regional management of Double-crested Cormorants. Pages 87-94 in Proceedings of the $10^{\text {th }}$ Wildlife Damage Management Conference $(\mathrm{K}$. A. Fagerstone and G. W. Witmer, Eds.). U.S. Department of Agriculture National Wildlife Research Center. University of Nebraska, Lincoln, Nebraska.

Bedard, J., A. Nadeau and M. Lepage. 1999. Doublecrested Cormorant culling in the St. Lawrence River Estuary: results of a 5-year program. Pages 147-156 in Symposium on Double-crested Cormorants: Population Status and Management Issues in the Midwest. Technical Bulletin No. 1879 (M. E. Tobin, Tech. Coord.). U.S. Department of Agriculture, Animal and Plant Health Inspection Service, Wildlife Services, Washington, D.C.

Blackwell, B. F., M. A. Stapanian and D. V. C. Weseloh. 2002. Dynamics of the Double-crested Cormorant population on Lake Ontario. Wildlife Society Bulletin 30: 345-353.

Chipman, R. B., M. E. Richmond, J. T. Gansowski, K. J. Preusser, D. L. Stang, J. Coleman and D. Slate. 2000. Bada bang, bada boom: Dispersal of fall migrating cormorants to protect sportfish on Oneida Lake, New York. Page 46 in Proceedings of the $9^{\text {rh }}$ Wildlife Damage Management Conference (M. C. Brittingham, J. Kays and R. McPeacke, Eds.). State College, Pennsylvania.

Claypoole, K. 1988. First nesting of the Double-crested Cormorant at Oneida Lake, New York. Kingbird 38: 235-236.

Connelly, N. A. and T. L. Brown. 1991. Net economic value of the freshwater recreational fisheries in New York. Transactions of the American Fisheries Society 120: 770-775.

Hatch, J. J. 1995. Changing populations of Double-crested Cormorants. Colonial Waterbirds 18 (Special Publication 1): 8-24.

Hatch, J. J. and D. V. Weseloh. 1999. Double-crested Cormorant (Phalacrocorax auritus). In The Birds of North America, No. 441 (A. Poole and F. Gill, Eds.). The Birds of North America, Inc., Philadelphia, Pennsylvania.

Hebert, C. E., J. Duffe, D. V. C. Weseloh, E. M. T. Senese and G. D. Haffner. 2005. Unique island habitats may be threatened by Double-crested Cormorants. Journal of Wildlife Management 69: 68-76.

Jarvie, S., H. Blokpoel and T. Chipperfield. 1999. A geographic information system to monitor nest distributions of Double-crested Cormorants and Blackcrowned Night-herons at shared colony sites near Toronto, Canada. Pages 121-129 in Symposium on Double-crested Cormorants: Population Status and Management Issues in the Midwest. Technical Bulletin No. 1879 (M. E. Tobin, Tech. Coord.). U.S. Department of Agriculture, Animal and Plant Health Inspection Service, Washington, D.C.

Lemmon, C. R., G. Bugbee and G. R. Stephens. 1994. Tree damage by nesting Double-crested Cormorants in Connecticut. Connecticut Warbler 14: 27-30.
Mattison, P. M. 2006. Quantifying disturbance factors and effects in Common Terns (Sterna hirundo) using visual, audio, and reproductive data. Unpublished M.Sc. Thesis, Cornell University, Ithaca, New York.

Mills, E. L., J. L. Forney, M. D. Clady and W. R. Schaffner. 1978. Oneida Lake. Lakes of New York State. Volume II. Academic Press, New York, New York.

Rudstam, L. G., A. J. VanDeValk, C. M. Adams, J. T. H. Coleman, J. L. Forney and M. E. Richmond. 2004. Cormorant predation and the population dynamics of Walleye and Yellow Perch in Oneida Lake. Ecological Applications 14: 149-163.

Shieldcastle, M. C. and L. Martin. 1999. Colonial waterbird nesting on West Sister Island National Wildlife Refuge and the arrival of double-crested cormorants. Pages 115-119 in Symposium on Double-crested Cormorants: Population Status and Management Issues in the Midwest. Technical Bulletin No. 1879 (M. E. Tobin, Tech. Coord.). U.S. Department of Agriculture, Animal and Plant Health Inspection Service, Washington, D.C.

Shonk, K. A., S. D. Kevan and D. V. Weseloh. 2004. The effect of oil spraying on eggs of Double-crested Cormorants. The Environmentalist 24: 119-124.

Taylor, J. D. and B. S. Dorr. 2003. Double-crested Cormorant impacts to commercial and natural resources. Pages 43-51 in Proceedings of the $10^{\text {th }}$ Wildlife Damage Management Conference (K. A. Fagerstone and G. W. Witmer, Eds.). U.S. Department of Agriculture National Wildlife Research Center. University of Nebraska, Lincoln, Nebraska.

USDI FWS (U.S. Department of the Interior Fish and Wildlife Service). 2003. Migratory Bird Permits: Regulations for Double Crested Cormorant Management. Federal Register 68: 12653-12660.

VanDeValk, A. J., C. M. Adams, L. G. Rudstam, J. L. Forney, T. E. Brooking, M. Gerken, B. Young and J. Hooper. 2002. Comparison of angler and cormorant harvest of Walleye and Yellow Perch in Oneida Lake, New York. Transactions of the American Fisheries Society 131: 27-39.

VanDeValk, A. J., L. G. Rudstam, J. R. Jackson, T. E. Brooking, S. D. Krueger, J. L. Forney, W. W. Fetzer, E. L. Mills and T. L. DeVault. 2007. Walleye stock assessment and population projections for Oneida Lake, 2006-2009. New York Federal Aid in Sport Fish Restoration Study VII, Job 103, F-48-R. New York State Department of Environmental Conservation, Albany, New York.

Weseloh, D. V. and P. J. Ewins. 1994. Characteristics of a rapidly increasing colony of Double-crested Cormorants (Phalacrocorax auritus) in Lake Ontario: Population size, reproductive parameters and band recoveries. Journal of Great Lakes Research 20: 443456.

Weseloh, D. V. C., P. J. Ewins, J. Struger, P. Mineau, C. A. Bishop, S. Postupalsky and J. P. Ludwig. 1995. Doublecrested Cormorants of the Great Lakes: Changes in population size, breeding distribution, and reproductive output between 1913 and 1991. Colonial Waterbirds 18 (Special Publication 1): 48-59. 